\title{
BIOGENESIS OF ACCRETED CORDILLERAN RADIOLARITES: ORDOVICIAN- CRETACEOUS PROTO-PACIFIC PLANKTIC ENVIRONMENTS
}

CORDEY, Fabrice, Radiolarian Biostratigraphy, 311-1080 Pacific Street, Vancouver, BC V6E 4C2, Canada

Radiolarian biostratigraphic investigations and new chemical extraction techniques have led, over the past ten years, to the discovery of more than a thousand radiolarian chert (radiolarite) localities within most oceanic and pericratonic terranes of the western Canadian Cordillera, a segment of the Western American orogen.

Originally believed to be restricted to the Late Paleozoic, Canadian radiolarites progressively "expanded" in age to the Early Paleozoic and into the Mesozoic as shown by recent discoveries: from the craton to the outboard terranes, collections range in age from Ordovician (Selwyn Basin), to Early Cretaceous (Pacific Rim terrane), a time span of nearly $300 \mathrm{~m} . \mathrm{y}$. during which the westward time transgression of ocean/craton interaction, a geodynamic context dominated by plate convergence, can be tracked.

The oldest known radiolarian fauna from western Canada (Selwyn Basin), is correlative with the Haplentactinia juncta - Inanigutta unica Assemblage of Nazarov and Ormiston (1993) of Middle Ordovician age; Devonian and Carboniferous chert localities are known in Selwyn Basin and several allochtonous terranes; Permian chert is restricted to eastern and central terranes; Triassic-Jurassic radiolarite is well-represented within the central and western terranes; the youngest known association of Valanginian-Aptian age is from a chert melange matrix of the westernmost Pacific Rim terrane. With regard to paleogeography, most radiolarian associations from Permian to Jurassic chert have low paleolatitude, Eastern Tethyan affinities.

Some terranes are dominated by radiolarian chert sedimentation with a duration of nearly 180 m.y., while others show interlayering of carbonaceous and siliceous environments, also with a maximal duration of 180 m.y.. Chemical processing of chert reveals rare occurrences of spiculites associated with radiolarites. Most intervals of oceanic biogenetic sedimentation are capped with pre-accretionary hemipelagics and clastics, locally also radiolarian-bearing.

Radiolarian chert being a biogenetic product of surficial planktic productivity, Cordilleran chert sequences are believed to be linked to long-lived siliceous depocenters, probably a dominant feature of low and middle paleolatitude open ocean environments of the Paleozoic-Mesozoic proto-Pacific. The siliceous deposition may not have been continuous, as shown by global planktonic depletion over period boundaries such as that between the Permian and Triassic, where deposition of deep-sea clays is recorded in several circum-Pacific terranes. Radiolarians seemed to recover from each of these crises or depletion events, and dominate again the proto-Pacific pelagic environment as shown by the overall diversity of radiolarian fauna within radiolarite successions of Cordilleran terranes. 